\title{
Monetary Policy in Practice
}

\subsection{Exercises}

\subsubsection{Short Review Questions}

(a) Why is it that a decrease in the discount rate does not normally lead to an increase in borrowed reserves? Use the supply and demand analysis of the market for reserves to explain.

(b) Suppose that a central bank has just lowered the discount rate. Does this signal that the central bank is moving to a more expansionary monetary policy? Why or why not?

(c) Using the supply and demand analysis of the market for reserves, indicate what happens to the federal funds rate, borrowed reserves, and non-borrowed reserves if

1. The economy is unexpectedly strong, leading to an increase in the amount of bank deposits;

2. Banks expect an unusually large increase in withdrawals from deposit accounts in the future;

3. The Fed raises the target federal funds rate;

4. The Fed raises the interest rate on reserves above the current equilibrium federal funds rate;

5. The Fed reduces reserve requirements;

6. The Fed reduces reserve requirements, and then conducts an open market sale of securities.

\subsection{Solutions for Selected Exercises}

No solution provided. 